Fetal Diagnosis and Therapy
Fetal Diagn Ther 2013;33:215-223

DOI: $10.1159 / 000346806$
Received: December 26, 2012

Accepted after revision: January 4, 2013

Published online: March 5, 2013

\title{
Maternal Plasma Cell-Free Fetal and Maternal DNA at 11-13 Weeks' Gestation: Relation to Fetal and Maternal Characteristics and Pregnancy Outcomes
}

\author{
L.C.Y.Poon ${ }^{a}$ T. Muscic K. Song ${ }^{c}$ A. Syngelaki ${ }^{a}$ K.H. Nicolaides ${ }^{a}$ b
}

${ }^{a}$ Harris Birthright Research Centre for Fetal Medicine, King's College Hospital, and ${ }^{b}$ Department of Fetal Medicine,

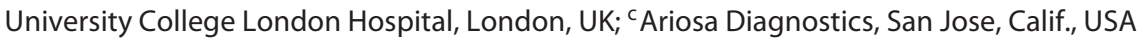

\section{Key Words}

Cell-free fetal DNA · Cell-free maternal DNA · First-trimester screening $\cdot$ Preeclampsia $\cdot$ Small for gestational age .

Preterm birth

\section{Abstract}

Objective: To examine the possible relationship between maternal and fetal characteristics and pregnancy outcomes on fetal and maternal cell-free (cf) DNA in maternal plasma at 11-13 weeks' gestation. Methods: cfDNA was extracted from maternal plasma of 1,949 singleton pregnancies and chromosome-selective sequencing was used to determine the proportion of cfDNA and total cfDNA counts which was of fetal and maternal origin. Multivariate regression analysis was used to determine whether specific maternal and fetal characteristics and pregnancy complications, such as preeclampsia (PE), early spontaneous preterm birth (SPB) and delivery of small for gestational age (SGA) neonates, were significant predictors of fetal and maternal cfDNA in maternal plasma. Results: The fetal and maternal cfDNA plasma concentration increased with serum pregnancy-associated plasma protein- $A$ and free $\beta$-human chorionic gonadotropin level, was higher in women of Afro-Caribbean and East-Asian racial origin than in Caucasians, and lower in smokers, but it was not significantly altered in pregnancies complicated by PE, SPB or SGA. The fetal cfDNA level was inversely related to maternal weight and uterine artery pulsatility index, and maternal cfDNA increased with maternal weight. Conclusions: The fetal and maternal cfDNA level in maternal plasma is affected by maternal and fetal characteristics, but it is not altered in pregnancy complications.

Copyright $\odot 2013$ S. Karger AG, Basel

\section{Introduction}

Analysis of cell-free DNA (cfDNA) in maternal blood can detect more than $99 \%$ of pregnancies with trisomy 21 at a false-positive rate of less than 1\% [1-9]. Consequently, this method is far superior to all currently available approaches to screening for trisomy 21 [10]. A potential issue with analysis of cfDNA as a universal screening test in all pregnant women is the failure rate in providing a result, which primarily depends on the relative proportion of fetal cfDNA to maternal cfDNA in maternal plasma. In trisomic pregnancies the number of molecules derived from the extra fetal chromosome, as a proportion of

\section{KARGER}

E-Mail karger@karger.com

www.karger.com/fdt
(C) 2013 S. Karger AG, Basel

1015-3837/13/0334-0215\$38.00/0
Prof. K.H. Nicolaides

Harris Birthright Research Centre for Fetal Medicine

King's College Hospital, Denmark Hill

London SE5 9RS (UK)

E-Mail kypros@fetalmedicine.com 
all sequenced molecules, is higher than in disomic pregnancies. The ability to detect this small increase in the amount of a given chromosome in maternal plasma in a trisomic pregnancy is directly related to the fetal fraction. If the fetal fraction is below $4 \%$, noninvasive prenatal testing is currently unable to provide a result $[2,3,7]$.

In a recent study of 1,949 singleton pregnancies undergoing first-trimester screening for aneuploidies as part of their routine antenatal care at 11-13 weeks' gestation, the median fraction of fetal cfDNA in maternal plasma was $10 \%$ [11]. Fetal fraction cfDNA in maternal plasma was determined by chromosome-selective sequencing of nonpolymorphic and polymorphic loci, where fetal alleles differ from maternal alleles [8]. The fetal fraction decreased with maternal weight, increased with fetal crown rump length (CRL), maternal serum level of free $\beta$-human chorionic gonadotropin ( $\beta$-hCG) and pregnancy-associated plasma protein-A (PAPP-A), was higher in smokers and in the presence of fetal trisomy 21 , and lower in women of Afro-Caribbean racial origin than in Caucasians. However, this study did not clarify whether the changes in fetal fraction were the consequence of altered levels in fetal or maternal cfDNA. For example, the finding that the fetal fraction was decreased in women of Afro-Caribbean racial origin could have been the consequence of decrease in fetal cfDNA, increase in maternal cfDNA, decrease in both fetal and maternal cfDNA (but more so for fetal cfDNA), or increase in both fetal and maternal cfDNA (but more so for maternal cfDNA).

The increase in fetal fraction with serum level of free $\beta$-hCG and PAPP-A has been attributed to the size of the placental mass, which is the common source of both cfDNA and metabolites [11]. However, several studies in pregnancies with male fetuses in which maternal plasma cfDNA level was estimated by amplification loci on the Y-chromosome reported that there is a 2- to 5-fold increase in cfDNA in preeclampsia (PE), which is associated with impaired placentation reflected in low first-trimester serum PAPP-A [12-16].

The objectives of this study comprising roughly 2,000 women undergoing routine screening for aneuploidies and adverse pregnancy outcomes at 11-13 weeks' gestation were (1) to examine the possible relationship between fetal and maternal characteristics on the maternal plasma concentrations of fetal and maternal cfDNA, and (2) secondly, to evaluate if there is a significant association between fetal and maternal cfDNA with PE, delivery of small for gestational age (SGA) neonates and early spontaneous preterm birth (SPB), which are thought to be associated with impaired placentation.

\section{Methods}

The data for this study were derived from analysis of stored maternal plasma obtained during prospective first-trimester combined screening for aneuploidies and adverse pregnancy outcomes in women with singleton pregnancies attending for their routine first hospital visit in pregnancy [17]. Patients agreeing to participate in the study, which was approved by the NHS National Research Ethics Service, provided written informed consent.

At $11^{+0}-13^{+6}$ weeks' gestation, we recorded maternal characteristics and medical history, including maternal racial origin (Caucasian, Afro-Caribbean, South Asian, East Asian and mixed), method of conception (spontaneous or assisted conception requiring the use of ovulation drugs or in vitro fertilization), cigarette smoking during pregnancy (yes or no), and measured maternal weight and height. We then performed a transabdominal ultrasound scan to (1) determine gestational age from the measurement of the fetal CRL, (2) diagnose any major fetal abnormalities, (3) measure fetal nuchal translucency (NT) thickness and (4) use color Doppler ultrasound to visualize the left and right uterine artery; we then measured the pulsatility index (PI) in each vessel and calculated the mean PI [18-21]. In addition, the maternal serum PAPP-A and free $\beta$-hCG were determined within $10 \mathrm{~min}$ of blood collection using automated machines that provide reproducible results (DELFIA Xpress system; PerkinElmer Life and Analytical Sciences, Waltham, Mass., USA). The measured NT was expressed as a difference from the expected normal mean for gestation (delta value) [20]. Similarly, the measured free $\beta$-hCG and PAPP-A were converted into the multiple of median (MoM) for gestational age adjusted for maternal weight, racial origin, smoking status, method of conception, parity and machine for the assays [22]. Biophysical and biochemical markers were combined to estimate the patient-specific risk for aneuploidies; women who considered their risk to be high were offered chorionic villus sampling for fetal karyotyping.

The population for this study included 1,949 pregnancies examined between October 2010 and January 2011 and in which cfDNA analysis was carried out in $2 \mathrm{ml}$ of stored maternal plasma. This is the same cohort as published in a previous report where sensitivity and specificity for trisomy detection was determined [9].

\section{Outcome Measures}

Demographic characteristics, ultrasonographic measurements and biochemical results were recorded in computer databases. Karyotype results, obtained from genetic laboratories, and details on pregnancy outcomes, obtained from the maternity computerized records or the general medical practitioners of the women, were added into the database as soon as they became available.

The definition of PE was that of the International Society for the Study of Hypertension in Pregnancy [23]. SGA was defined as birth weight below the 5 th percentile for gestational age of a normal range derived from our population [24]. Spontaneous preterm delivery was defined as delivery before 34 weeks' gestation as a result of presentation with preterm premature rupture of membranes and/or contractions. The obstetric records of patients with adverse pregnancy outcomes were examined to confirm the diagnosis. 
Laboratory Analysis

Venous blood was collected in ethylene diamine tetraacetic acid (EDTA) BD Vacutainer ${ }^{\mathrm{TM}}$ tubes (Becton Dickinson UK Ltd., Oxford, UK) and within 15 min of collection it was centrifuged at $2,000 \mathrm{~g}$ for $10 \mathrm{~min}$ and subsequently at $16,000 \mathrm{~g}$ for $10 \mathrm{~min}$. Plasma samples were then stored at $-80^{\circ} \mathrm{C}$ until subsequent analysis. The samples were sent overnight on dry ice from London, UK to the USA for analysis using a chromosome-selective assay (HarmonyTM Prenatal Test; Ariosa Diagnostics Inc., San Jose, Calif., USA). The laboratory personnel, who were unaware of the fetal karyotype, provided risk scores for trisomies 21 and 18 and the plasma concentrations of fetal and maternal cfDNA as determined by sequencing counts $[8,25]$.

In this study we report the maternal plasma concentrations in genomic equivalent (GE)/ml of fetal and maternal cfDNA. The estimated risks for trisomies 21 and 18 were published previously [9].

\section{Statistical Analyses}

Descriptive data were presented as the median and interquartile range for continuous variables and in numbers and percentages for categorical variables. Comparisons between outcome groups was by $\chi^{2}$ or Fisher's exact test for categorical variables and Mann-Whitney $U$ test for continuous variables, with post hoc Bonferroni correction with an adjusted $\mathrm{p}$ value of $<0.0125$.

The measured maternal plasma concentrations of fetal and maternal cfDNA were $\log _{10}$-transformed to make the distribution Gaussian. Normality of distribution was assessed using probability plot. Regression analysis was used to determine which of the factors amongst maternal weight, height, racial origin, smoking status, method of conception, $\log _{10}$ PAPP-A, $\log _{10}$ free $\beta$-hCG, fetal CRL, delta NT, fetal gender and karyotype, $\log _{10}$ uterine artery $\mathrm{PI}$, and adverse pregnancy outcomes were significant predictors of $\log _{10}$ values of fetal and maternal cfDNA.

The statistical software package SPSS 20.0 (SPSS Inc.,Chicago, Ill., USA) was used for data analyses.

\section{Results}

Maternal characteristics, results of the combined test and maternal plasma concentrations of fetal and maternal cfDNA of the study population of 1,949 cases are presented in table 1 . The population included 8 cases of trisomy 21, 2 of trisomy 18 and 1,939 euploid pregnancies [9]. In the euploid group there were 46 cases that developed PE, 68 cases that delivered SGA neonates in the absence of PE and 20 cases of SPB before 34 weeks' gestation.

In PE patients, the median maternal weight and uterine artery PI were significantly higher, and there was a higher prevalence of women of Afro-Caribbean racial origin. In SGA without PE, the median maternal weight and height were significantly lower, the uterine artery PI was higher, and there was a higher prevalence of cigarette smokers. The median maternal plasma concentrations of fetal and maternal cfDNA in the total population were 13.30 GE/ml (10.05-17.86) and $114.93 \mathrm{GE} / \mathrm{ml}(80.53-$ 164.01), respectively. There was no significant difference in plasma concentration of fetal cfDNA between the outcome groups, but in $\mathrm{PE}$ the concentration of maternal cfDNA was increased.

Univariate regression analysis demonstrated that $\log _{10}$ fetal cfDNA was significantly associated with maternal weight, height, racial origin, smoking status, fetal CRL, fetal gender, trisomy 21 karyotype, $\log _{10}$ PAPP-A, $\log _{10}$ free $\beta$-hCG and $\log _{10}$ uterine artery PI, but not method of conception, delta NT, trisomy 18 karyotype, PE, SGA or SPB (table 2). Multivariate regression analysis demonstrated that significant independent prediction of $\log _{10}$ fetal cfDNA was provided by maternal weight, Afro-Caribbean and East Asian racial origin, smoking status, $\log _{10}$ values of PAPP-A, free $\beta$-hCG and uterine artery PI, but not maternal height, fetal CRL, fetal gender or karyotype $\left(\mathrm{R}^{2}=0.318\right.$; table 2$)$. Fetal cfDNA concentration was $7 \%$ higher in women of Afro-Caribbean origin, $12 \%$ higher in East Asians and 14\% lower in smokers. The correlations between fetal cfDNA with maternal weight and serum concentrations of PAPP-A and free $\beta$-hCG are illustrated in figures 1-3.

Univariate regression analysis demonstrated that $\log _{10}$ maternal cfDNA was significantly associated with maternal weight, Afro-Caribbean, South and East Asian racial origin, smoking status, $\log _{10}$ PAPP-A, $\log _{10}$ free $\beta$-hCG and $\mathrm{PE}$ but not maternal height, method of conception, fetal CRL, fetal gender, karyotype, delta NT, $\log _{10}$ uterine artery PI, SGA or SPB (table 2). Multivariate regression analysis demonstrated that significant independent prediction of $\log _{10}$ maternal cfDNA was provided by maternal weight, racial origin, smoking status, $\log _{10}$ values of PAPP-A and free $\beta$-hCG but not PE $\left(\mathrm{R}^{2}=0.120\right.$, table 3$)$. Maternal cfDNA concentration was 25\% higher in women of Afro-Caribbean origin, $17 \%$ higher in South Asians, $16 \%$ higher in East Asians and 22\% lower in smokers. The correlations between maternal cfDNA with maternal weight and serum concentrations of PAPP-A and free $\beta$-hCG are illustrated in figures $1-3$.

There was a significant association between fetal cfD$\mathrm{NA}$ and maternal cfDNA $(\mathrm{r}=0.655, \mathrm{p}<0.0001$; fig. 4).

\section{Discussion}

The findings of this study demonstrate that there is a significant association between the level of fetal and maternal cfDNA in maternal plasma at 11-13 weeks' gesta- 
Fig. 1. Relationship of maternal weight with maternal plasma concentration of fetal (left) and maternal (right) cfDNA: PE (red circles) and unaffected (black circles).

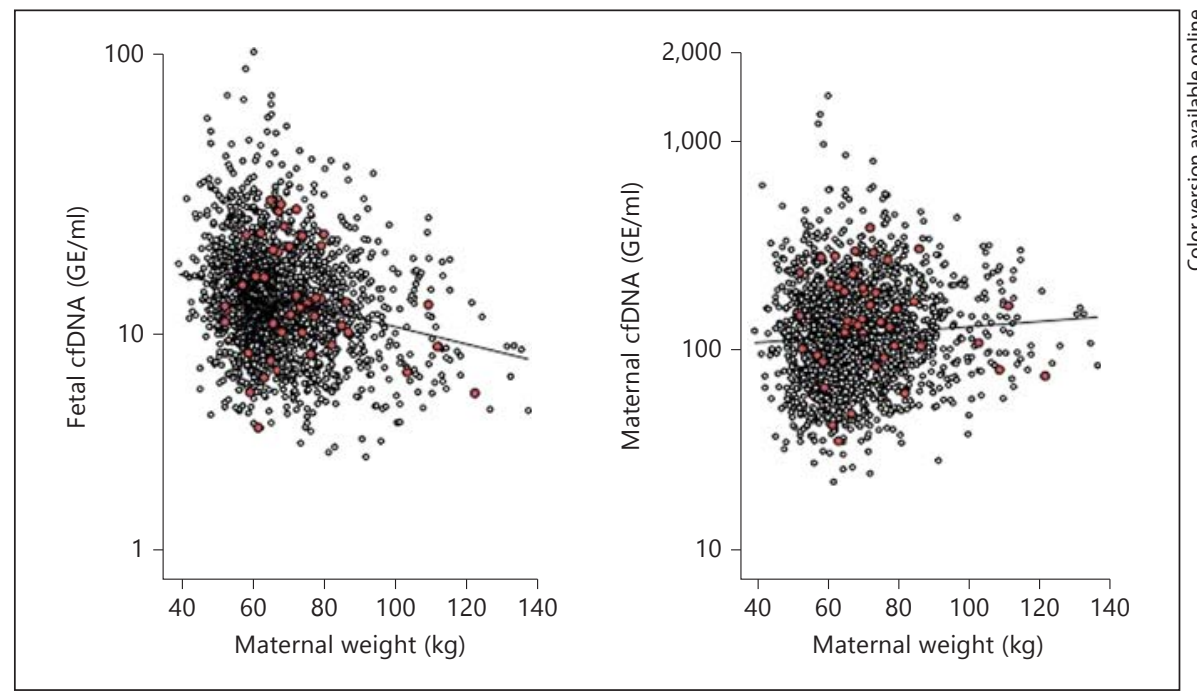

Table 1. Maternal and fetal characteristics of the study population

\begin{tabular}{|c|c|c|c|c|c|c|}
\hline Characteristics & $\begin{array}{l}\text { Total } \\
(\mathrm{n}=1,949)\end{array}$ & $\begin{array}{l}\text { Normal } \\
(\mathrm{n}=1,805)\end{array}$ & $\begin{array}{l}\text { Aneuploidy } \\
(\mathrm{n}=10)\end{array}$ & $\begin{array}{l}\mathrm{PE} \\
(\mathrm{n}=46)\end{array}$ & $\begin{array}{l}\text { SGA } \\
(n=68)\end{array}$ & $\begin{array}{l}\text { SPB } \\
(n=20)\end{array}$ \\
\hline Maternal age, years & $\begin{array}{l}31.8 \\
(27.8-35.3)\end{array}$ & $\begin{array}{l}31.9 \\
(27.8-35.4)\end{array}$ & $\begin{array}{l}39.6 \\
(31.7-42.0)^{*}\end{array}$ & $\begin{array}{l}29.7 \\
(24.8-33.6)\end{array}$ & $\begin{array}{l}30.5 \\
(26.6-34.7)\end{array}$ & $\begin{array}{l}30.9 \\
(26.3-34.0)\end{array}$ \\
\hline Maternal weight, $\mathrm{kg}$ & $\begin{array}{l}65.0 \\
(58.3-75.9)\end{array}$ & $\begin{array}{l}65.0 \\
(58.4-75.0)\end{array}$ & $\begin{array}{l}63.0 \\
(60.0-80.2)\end{array}$ & $\begin{array}{l}69.9 \\
(63.0-77.9)^{*}\end{array}$ & $\begin{array}{l}60.8 \\
(55.5-70.9)^{*}\end{array}$ & $\begin{array}{l}64.7 \\
(58.0-74.4)\end{array}$ \\
\hline Maternal height, $\mathrm{cm}$ & $\begin{array}{l}164 \\
(160-169)\end{array}$ & $\begin{array}{l}164 \\
(160-169)\end{array}$ & $\begin{array}{l}167 \\
(163-168)\end{array}$ & $\begin{array}{l}165 \\
(160-169)\end{array}$ & $\begin{array}{l}162 \\
(157-165)^{*}\end{array}$ & $\begin{array}{l}164 \\
(162-170)\end{array}$ \\
\hline \multicolumn{7}{|l|}{ Racial origin } \\
\hline Caucasian & $1,377(70.7)$ & $1,303(72.2)$ & $7(70.0)$ & $20(43.5)^{*}$ & $35(51.5)^{*}$ & $12(60.0)$ \\
\hline Afro-Caribbean & $390(20.0)$ & $340(18.8)$ & $3(30.0)$ & $21(45.7)^{*}$ & $21(30.9)$ & $5(25.0)$ \\
\hline South Asian & $77(4.0)$ & $66(3.7)$ & 0 & $4(8.7)$ & $6(8.8)$ & $1(5.0)$ \\
\hline East Asian & $54(2.8)$ & $50(2.8)$ & 0 & 0 & $3(4.4)$ & $1(5.0)$ \\
\hline Mixed & $51(2.6)$ & $46(2.5)$ & 0 & $1(2.2)$ & $3(4.4)$ & $1(5.0)$ \\
\hline Cigarette smoker & $120(6.2)$ & $105(5.8)$ & 0 & $1(2.2)$ & $14(20.6)^{*}$ & 0 \\
\hline \multicolumn{7}{|l|}{ Method of conception } \\
\hline Spontaneous & $1,910(98.0)$ & $1,771(98.1)$ & $10(100.0)$ & $44(95.7)$ & $67(98.5)$ & $18(90.0)$ \\
\hline Ovulation drugs & $19(1.0)$ & $17(0.9)$ & 0 & $1(2.2)$ & $1(1.5)$ & 0 \\
\hline In vitro fertilization & $20(1.0)$ & $17(0.9)$ & 0 & $1(2.2)$ & 0 & $2(10.0)$ \\
\hline Fetal CRL, mm & 62.4 & 62.6 & 62.6 & 61.8 & 60.4 & 60.5 \\
\hline \multicolumn{7}{|l|}{ Fetal gender } \\
\hline Male & $1,010(51.8)$ & $944(52.3)$ & $5(50.0)$ & $23(50.0)$ & $30(44.1)$ & $8(40.0)$ \\
\hline Female & $939(48.2)$ & $861(47.7)$ & $5(50.0)$ & $23(50.0)$ & $38(55.9)$ & $12(60.0)$ \\
\hline Delta NT & $\begin{array}{l}0.11 \\
(-0.09-0.35)\end{array}$ & $\begin{array}{l}0.11 \\
(-0.08-0.35)\end{array}$ & $\begin{array}{l}2.00 \\
(0.99-4.44)^{*}\end{array}$ & $\begin{array}{l}0.07 \\
(-0.15-0.30)\end{array}$ & $\begin{array}{l}0.06 \\
(-0.12-0.35)\end{array}$ & $\begin{array}{l}0.06 \\
(-0.12-0.30)\end{array}$ \\
\hline PAPP-A & $\begin{array}{l}2.85 \\
(1.85-4.39)\end{array}$ & $\begin{array}{l}2.87 \\
(1.87-4.40)\end{array}$ & $\begin{array}{l}1.14 \\
(0.59-3.55)\end{array}$ & $\begin{array}{l}2.47 \\
(1.38-3.18)\end{array}$ & $\begin{array}{l}2.76 \\
(1.51-4.41)\end{array}$ & $\begin{array}{l}2.61 \\
(1.91-3.69)\end{array}$ \\
\hline Free $\beta$-hCG & $\begin{array}{l}37.47 \\
(24.86-58.01)\end{array}$ & $\begin{array}{l}37.29 \\
(24.85-57.11)\end{array}$ & $\begin{array}{l}91.12 \\
(22.19-191.21)\end{array}$ & $\begin{array}{l}36.56 \\
(24.1-57.87)\end{array}$ & $\begin{array}{l}42.45 \\
(26.13-61.00)\end{array}$ & $\begin{array}{l}34.26 \\
(25.30-67.56)\end{array}$ \\
\hline Uterine artery PI & $\begin{array}{l}1.70 \\
(1.38-2.05)\end{array}$ & $\begin{array}{l}1.69 \\
(1.37-2.02)\end{array}$ & $\begin{array}{l}1.66 \\
(1.23-2.29)\end{array}$ & $\begin{array}{l}1.96 \\
(1.62-2.31)^{*}\end{array}$ & $\begin{array}{l}2.05 \\
(1.62-2.40)^{*}\end{array}$ & $\begin{array}{l}1.88 \\
(1.58-2.15)\end{array}$ \\
\hline \multicolumn{7}{|l|}{$\mathrm{cfDNA}, \mathrm{GE} / \mathrm{ml}$} \\
\hline Fetal & $\begin{array}{l}13.30 \\
(10.05-17.86)\end{array}$ & $\begin{array}{l}13.29 \\
(10.06-17.73)\end{array}$ & $\begin{array}{l}18.20 \\
(12.50-26.22)\end{array}$ & $\begin{array}{l}12.87 \\
(9.94-20.92)\end{array}$ & $\begin{array}{l}15.47 \\
(9.23-19.60)\end{array}$ & $\begin{array}{l}12.80 \\
(10.37-19.62)\end{array}$ \\
\hline Maternal & $\begin{array}{l}114.93 \\
(80.53-164.01)\end{array}$ & $\begin{array}{l}113.86 \\
(80.16-163.81)\end{array}$ & $\begin{array}{l}131.08 \\
(98.61-154.84)\end{array}$ & $\begin{array}{l}138.30 \\
(98.80-200.07)^{*}\end{array}$ & $\begin{array}{l}111.16 \\
(70.14-138.30)\end{array}$ & $\begin{array}{l}136.38 \\
(106.97-186.71)\end{array}$ \\
\hline
\end{tabular}

Values are either medians (interquartile range) or $\mathrm{n}(\%)$. Comparisons between adverse outcome groups and normal are by Mann-Whitney $\mathrm{U}$ test for continuous variables and by $\chi^{2}$ or Fisher's exact test for categorical variables, with post hoc Bonferroni correction with an adjusted $\mathrm{p}$ value of $<0.0125(*)$. 
Fig. 2. Relationship of maternal serum PAPP-A with maternal plasma concentration of fetal (left) and maternal (right) cfDNA: PE (red circles) and unaffected (black circles).
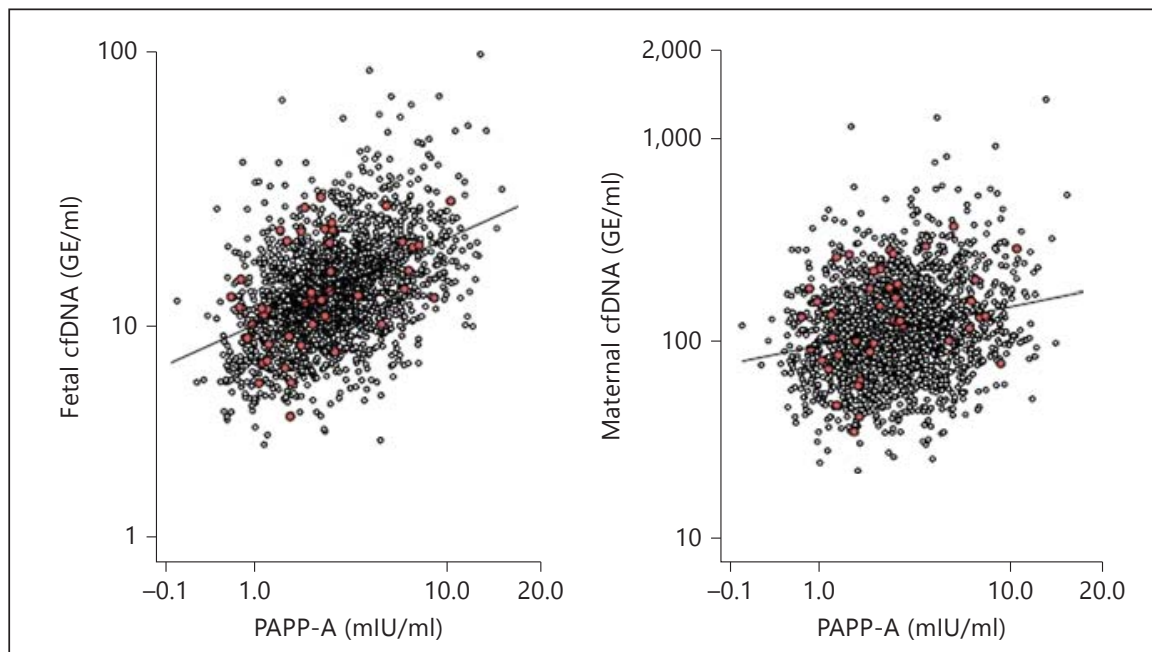

Table 2. Regression analysis for the prediction of $\log _{10}$ fetal cfDNA $\left(\log _{10} \mathrm{GE} / \mathrm{ml}\right)$

\begin{tabular}{|c|c|c|c|c|}
\hline Independent variable & \multicolumn{2}{|l|}{ Univariate } & \multicolumn{2}{|l|}{ Multivariate } \\
\hline Maternal height $(\mathrm{cm})$ & $-0.003(-0.004$ to -0.001$)$ & $<0.0001^{*}$ & $-0.0002(-0.001$ to 0.001$)$ & 0.753 \\
\hline \multicolumn{5}{|l|}{ Racial origin } \\
\hline Caucasian & 0 & & & \\
\hline East Asian & $0.101(0.048$ to 0.154$)$ & $<0.0001^{*}$ & $0.048(0.002$ to 0.093$)$ & $0.040^{*}$ \\
\hline Mixed & $-0.0001(-0.055$ to 0.055$)$ & 0.998 & - & - \\
\hline Smoking & $-0.104(-0.141$ to -0.068$)$ & $<0.0001^{*}$ & $-0.064(-0.096$ to -0.032$)$ & $<0.0001^{*}$ \\
\hline \multicolumn{5}{|l|}{ Method of conception } \\
\hline Spontaneous & 0 & & & \\
\hline Ovulation drugs & $0.013(-0.077$ to 0.103$)$ & 0.775 & - & - \\
\hline Male & 0 & & 0 & \\
\hline Female & $0.026(0.008$ to 0.044$)$ & $0.004^{*}$ & $0.005(-0.010$ to 0.020$)$ & 0.517 \\
\hline \multicolumn{5}{|l|}{ Karyotype } \\
\hline Euploid & 0 & & & \\
\hline Trisomy 21 & $0.175(0.037$ to 0.313$)$ & $0.013^{*}$ & $0.092(-0.054$ to 0.238$)$ & 0.215 \\
\hline Trisomy 18 & $-0.114(-0.389$ to 0.161$)$ & 0.417 & - & - \\
\hline Delta NT (mm) & $-0.009(-0.029$ to 0.010$)$ & 0.354 & - & - \\
\hline $\log _{10}$ PAPP-A & $0.317(0.289$ to 0.344$)$ & $<0.0001^{*}$ & 0.237 (0.207 to 0.266$)$ & $<0.0001^{*}$ \\
\hline $\log _{10} \beta-\mathrm{hCG}$ & $0.276(0.247$ to 0.305$)$ & $<0.0001^{*}$ & $0.221(0.194$ to 0.249$)$ & $<0.0001^{*}$ \\
\hline $\log _{10}$ uterine artery PI & $-0.121(-0.193$ to -0.049$)$ & $0.001^{*}$ & $-0.123(-0.184$ to -0.061$)$ & $<0.0001^{*}$ \\
\hline \multicolumn{5}{|c|}{ Adverse pregnancy outcome } \\
\hline $\mathrm{PE}$ & $-0.004(-0.062$ to 0.055$)$ & 0.904 & - & - \\
\hline
\end{tabular}


Fig. 3. Relationship of maternal serum free $\beta$-hCG with maternal plasma concentration of fetal (left) and maternal (right) cfDNA: PE (red circles) and unaffected (black circles).

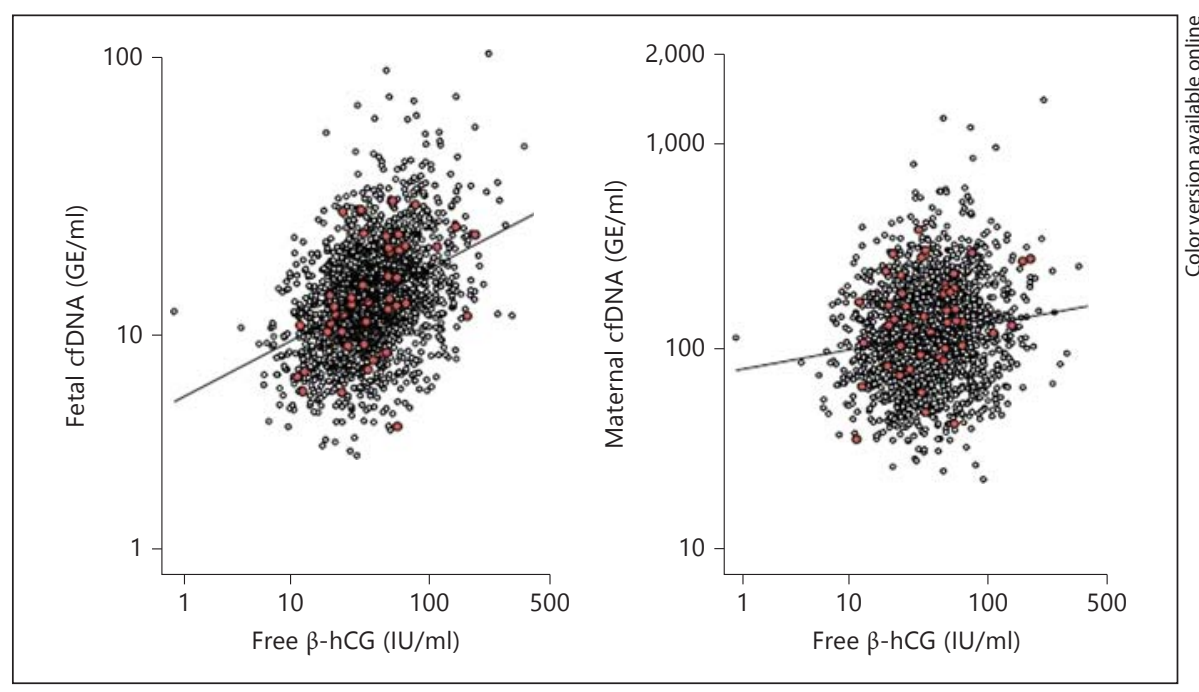

Table 3. Regression analysis for the prediction of $\log _{10}$ maternal cfDNA ( $\left.\log _{10} \mathrm{GE} / \mathrm{ml}\right)$

\begin{tabular}{|c|c|c|c|c|}
\hline \multirow[t]{2}{*}{ Independent variable } & \multicolumn{2}{|l|}{ Univariate } & \multicolumn{2}{|l|}{ Multivariate } \\
\hline & $\begin{array}{l}\text { regression coefficient } \\
(95 \% \mathrm{CI})\end{array}$ & $\mathrm{p}$ value & $\begin{array}{l}\text { regression coefficient } \\
(95 \% \mathrm{CI})\end{array}$ & $\mathrm{p}$ value \\
\hline Maternal height $(\mathrm{cm})$ & $-0.001(-0.002$ to 0.001$)$ & 0.492 & - & - \\
\hline \multicolumn{5}{|l|}{ Racial origin } \\
\hline Caucasian & 0 & & & \\
\hline East Asian & $0.077(0.015$ to 0.139$)$ & $0.015^{*}$ & $0.065(0.005$ to 0.126$)$ & $0.035^{*}$ \\
\hline Mixed & $0.005(-0.059$ to 0.069$)$ & 0.874 & - & - \\
\hline Smoking & $-0.143(-0.186$ to -0.100$)$ & $<0.0001^{*}$ & $-0.108(-0.149$ to -0.067$)$ & $<0.0001^{*}$ \\
\hline \multicolumn{5}{|l|}{ Method of conception } \\
\hline Spontaneous & 0 & & & \\
\hline Ovulation drugs & $-0.0002(-0.106$ to 0.106$)$ & 0.998 & - & - \\
\hline Female & $0.019(-0.002$ to 0.040$)$ & 0.075 & - & - \\
\hline \multicolumn{5}{|l|}{ Karyotype } \\
\hline Euploid & 0 & & & \\
\hline Trisomy 21 & $0.053(-0.110$ to 0.216$)$ & 0.525 & - & - \\
\hline Trisomy 18 & $-0.025(-0.351$ to 0.301$)$ & 0.881 & - & - \\
\hline Delta NT (mm) & $-0.002(-0.025$ to 0.021$)$ & 0.868 & - & - \\
\hline $\log _{10}$ PAPP-A & $0.178(0.142$ to 0.215$)$ & $<0.0001^{*}$ & $0.133(0.095$ to 0.171$)$ & $<0.0001^{*}$ \\
\hline $\log _{10} \beta-\mathrm{hCG}$ & $0.124(0.088$ to 0.161$)$ & $<0.0001^{*}$ & $0.110(0.074$ to 0.146$)$ & $<0.0001^{*}$ \\
\hline $\log _{10}$ uterine artery PI & $-0.081(-0.167$ to 0.005$)$ & 0.064 & - & - \\
\hline \multicolumn{5}{|c|}{ Adverse pregnancy outcome } \\
\hline $\mathrm{PE}$ & $0.076(0.007$ to 0.145$)$ & $0.030^{*}$ & $0.043(-0.022$ to 0.108$)$ & 0.198 \\
\hline
\end{tabular}




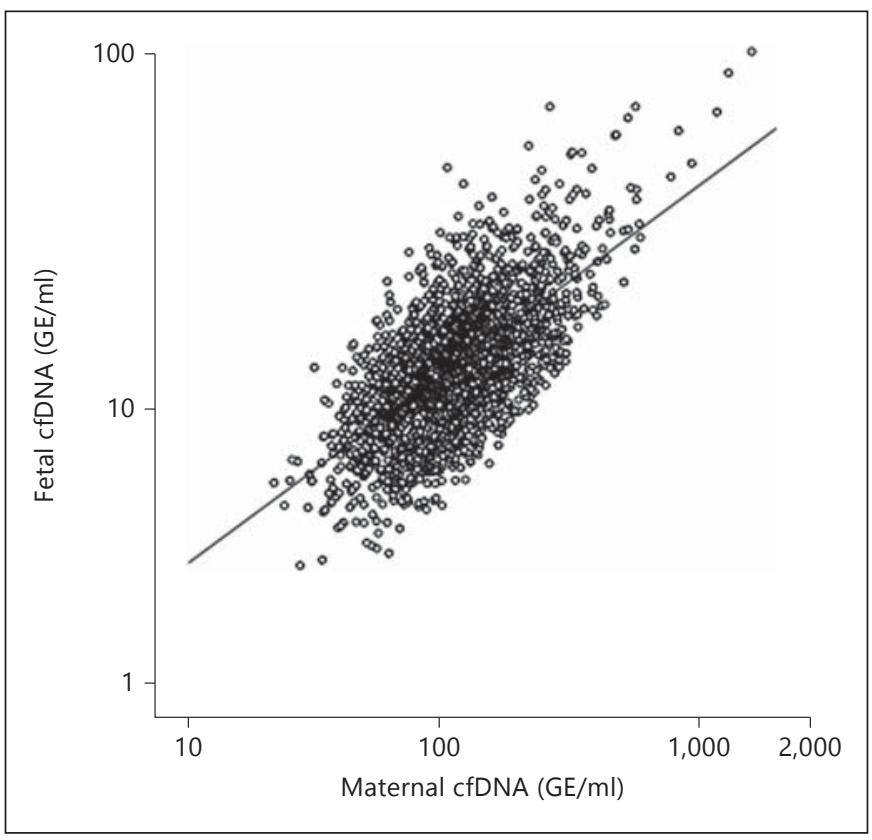

Fig. 4. Relationship between fetal and maternal cfDNA.

tion. They both increase with serum PAPP-A and free $\beta$-hCG, are higher in women of Afro-Caribbean and East Asian racial origin than in Caucasians, and lower in smokers, but they are not significantly altered in pregnancies complicated by PE, SGA or SPB. Fetal cfDNA levels are inversely related to maternal weight and uterine artery PI and maternal cfDNA increases with maternal weight and is higher in women of South-Asian racial origin than in Caucasians.

A potential source of fetal cfDNA in maternal plasma is dying cells in the placenta and inevitably the number of apoptotic cells would be proportional to the placental mass, reflected in the serum concentration of free $\beta$-hCG and PAPP-A, which are also produced by the placenta [26]. The findings that Afro-Caribbean and East-Asian women, compared to Caucasians, have a higher concentration of fetal cfDNA can at least in part be explained by increased placental mass and/or activity in these racial groups reflected in the serum levels of free $\beta$-hCG and PAPP-A. The levels of free $\beta$-hCG and PAPP-A in AfroCaribbean women, compared to Caucasians, are higher by 12 and 57\%, respectively, and the respective values for East Asians are 8 and 9\% [22]. In women of South Asian racial origin, the fetal cfDNA level is not significantly altered and serum PAPP-A is increased by $3 \%$, but free $\beta$-hCG is decreased by $9 \%$ [22]. In smokers, where fetal cfDNA is decreased by $14 \%$, serum free $\beta$-hCG and
PAPP-A are decreased by 4 and 17\%, respectively [22]. Although in smokers fetal cfDNA would be expected to be elevated because the constituents of tobacco increase syncytiotrophoblastic necrosis $[27,28]$, the opposite is true, possibly reflecting the impaired placental development and decreased placental mass in such patients. Uterine artery PI provides an indirect measure of the physiological process whereby trophoblastic invasion and remodeling of spiral arteries converts them from high to low impedance vessels [29]. It would therefore be expected that there is an inverse association between uterine artery PI and placental mass and consequently plasma fetal cfDNA level.

In nonpregnant individuals, the most likely mechanism leading to the release of cfDNA into their circulation is apoptosis or some other form of cell death and the concentration of circulating cfDNA is increased in patients with malignant disorders or injuries [30-33]. If in pregnancy cell death is also the mechanism governing the concentration of plasma maternal cfDNA, our findings suggest that the fetoplacental unit, by some hitherto unknown mechanisms, influences such maternal apoptosis. This is reflected in the high association between maternal cfDNA and fetal cfDNA levels, as well as the finding that both maternal and fetal cfDNA levels increase with serum free $\beta$-hCG and PAPP-A, are higher in women of AfroCaribbean and East Asian racial origin than in Caucasians, and lower in smokers. The only difference between fetal and maternal cfDNA levels is observed in relation to maternal weight. The decrease in fetal cfDNA with maternal weight is compatible with the plasma concentration of other fetoplacental products and can be attributed to a dilutional effect [22]. In contrast, maternal cfDNA levels increase with weight and recent evidence suggests that with increased weight there is active remodeling of adipose tissue with accelerated turnover of adipocytes [34].

We have previously reported that the fetal fraction is decreased in women of Afro-Caribbean racial origin and increased in smokers [11]. This study demonstrates that in women of Afro-Caribbean racial origin there is an increase in both fetal and maternal cfDNA, but more so for maternal cfDNA. In smokers there is a decrease in both fetal and maternal cfDNA, but more so for maternal cfDNA.

In pregnancies complicated by $\mathrm{PE}, \mathrm{SGA}$ or $\mathrm{SPB}$, the maternal plasma level of fetal and maternal cfDNA at 1113 weeks' gestation was not significantly different from normal pregnancies. Previous studies reported that plasma cfDNA levels are increased in pregnancies with clini- 
cally established PE [13-16], which has been attributed to placental ischemia, with release into the maternal circulation of necrotic or apoptotic syncytiotrophoblast fragments that contain fetal cfDNA $[15,35]$. Some contradictory evidence suggests that in cases of early-onset PE the increase in cfDNA precedes the clinical onset of the disease and may be apparent from the first trimester of pregnancy [35-38]. In SGA without PE, one study reported increased plasma cfDNA [39], but in another study there was no significant difference from normal pregnancies [40]. Similarly, there is contradictory evidence as to whether any increase in fetal cfDNA in association with SGA precedes the clinical presentation of impaired fetal growth $[36,38]$.

There is some evidence that plasma fetal cfDNA is increased in pregnancies complicated by SPB with a suggested mechanism of early initiation of breakdown of the placental barrier in anticipation of labor [41]. Two studies examined women presenting with contractions and/or premature rupture of membranes and reported a correlation between fetal cfDNA levels and subsequent delivery $[42,43]$. A cohort study of women undergoing routine fetal RHD genotyping at 25 weeks' gestation reported that if the fetal cfDNA levels were above the 95th percentile there was a 16-fold increase in risk for SPB before 34 weeks [44]. In contrast, a study examining women with short cervical length at 22-24 weeks reported no significant difference in the level of fetal cfDNA between those that delivered before 37 weeks compared to those delivering at term [45]. Our study indicates that neither fetal nor maternal cfDNA levels at 11-13 weeks are altered in pregnancies with subsequent SPB.

In conclusion, the maternal plasma level of fetal cfDNA at 11-13 weeks' gestation increases with markers of placental size and decreases with maternal weight. There is a high association between fetal and maternal cfDNA levels suggesting that placental factors are also affecting maternal cell death. The levels of both fetal and maternal cfDNA at 11-13 weeks are not significantly altered in pregnancies that are complicated by PE, SGA and SPB. The implications of this finding are that (1) assessment of fetal and maternal cfDNA levels is unlikely to be useful in early prediction for these pregnancy complications, and (2) successful universal application of plasma cfDNA testing in screening for aneuploidies will not be hindered in pregnancies at high risk for PE, SGA or SPB.

\section{Disclosure Statement}

T.M. and K.S. are paid employees of Ariosa Diagnostics. The study was supported by a grant from The Fetal Medicine Foundation (UK Charity No: 1037116). The cost of collection and analysis of the samples was covered by Ariosa Diagnostics Inc., San Jose, Calif., USA.

\section{References}

1 Chiu RW, Akolekar R, Zheng YW, Leung TY, Sun H, Chan KC, Lun FM, Go AT, Lau ET, To WW, Leung WC, Tang RY, Au-Yeung SK, Lam H, Kung YY, Zhang X, van Vugt JM, Minekawa R, Tang MH, Wang J, Oudejans CB, Lau TK, Nicolaides KH, Lo YM: Non-invasive prenatal assessment of trisomy 21 by multiplexed maternal plasma DNA sequencing: large scale validity study. BMJ 2011;342:c7401.

- 2 Ehrich M, Deciu C, Zwiefelhofer T, Tynan JA, Cagasan L, Tim R, Lu V, McCullough R, McCarthy E, Nygren AO, Dean J, Tang L, Hutchison D, Lu T, Wang H, Angkachatchai V, Oeth P, Cantor CR, Bombard A, van den Boom D: Noninvasive detection of fetal trisomy 21 by sequencing of DNA in maternal blood: a study in a clinical setting. Am J Obstet Gynecol 2011;204:205.e1-e11.

>3 Palomaki GE, Kloza EM, Lambert-Messerlian GM, Haddow JE, Neveux LM, Ehrich M, van den Boom D, Bombard AT, Deciu C, Grody WW, Nelson SF, Canick JA: DNA sequencing of maternal plasma to detect Down syndro- me: an international clinical validation study. Genet Med 2011;13:913-920.

4 Sehnert AJ, Rhees B, Comstock D, de Feo E, Heilek G, Burke J, Rava RP: Optimal detection of fetal chromosomal abnormalities by massively parallel DNA sequencing of cellfree fetal DNA from maternal blood. Clin Chem 2011;57:1042-1049.

5 Ashoor G, Syngelaki A, Wagner M, Birdir C, Nicolaides KH: Chromosome-selective sequencing of maternal plasma cell-free DNA for first-trimester detection of trisomy 21 and trisomy 18. Am J Obstet Gynecol 2012;206:322. e1-e5.

6 6 Bianchi DW, Platt LD, Goldberg JD, Abuhamad AZ, Sehnert AJ, Rava RP: Genome-wide fetal aneuploidy detection by maternal plasma DNA sequencing. Obstet Gynecol 2012; 119:890-901.

7 Norton ME, Brar H, Weiss J, Karimi A, Laurent LC, Caughey AB, Rodriguez MH, Williams J 3rd, Mitchell ME, Adair CD, Lee H, Jacobsson B, Tomlinson MW, Oepkes D, Hollemon D,
Sparks AB, Oliphant A, Song K: Non-invasive chromosomal evaluation (NICE) study: results of a multicenter prospective cohort study for detection of fetal trisomy 21 and trisomy 18 . Am J Obstet Gynecol 2012;207:137.e1-e8.

8 Sparks AB, Struble CA, Wang ET, Song K, Oliphant A: Optimized non-invasive evaluation of fetal aneuploidy risk using cell-free DNA from maternal blood. Am J Obstet Gynecol 2012;206:319.e1-e9.

-9 Nicolaides KH, Syngelaki A, Birdir C, Touzet G, Ashoor G: Noninvasive prenatal testing for fetal trisomies in an average-risk population. Am J Obstet Gynecol 2012;207:374.e1-e6.

10 Nicolaides KH: Screening for fetal aneuploidies at 11 to 13 weeks. Prenat Diagn 2011;31: 7-15.

11 Ashoor G, Syngelaki A, Poon LCY, Rezende JC, Nicolaides KH: Fetal fraction in maternal plasma cell-free DNA at 11-13 weeks' gestation: relation to maternal and fetal characteristics. Ultrasound Obstet Gynecol 2013;41:2632. 
$>12$ Poon LC, Maiz N, Valencia C, Plasencia W, Nicolaides KH: First-trimester maternal serum pregnancy-associated plasma protein-A and pre-eclampsia. Ultrasound Obstet Gynecol 2009;33:23-33.

13 Lo YM, Leung TN, Tein MS, et al: Quantitative abnormalities of fetal DNA in maternal serum in preeclampsia. Clin Chem 1999;45: $184-188$.

14 Zhong XY, Laivuori H, Livingston JC, et al: Elevation of both maternal and fetal extracellular circulating deoxyribonucleic acid concentrations in the plasma of pregnant women with preeclampsia. Am J Obstet Gynecol 2001;184: 414-419.

15 Farina A, Sekizawa A, Rizzo N, et al: Cell-free fetal DNA (SRY locus) concentration in maternal plasma is directly correlated to the time elapsed from the onset of preeclampsia to the collection of blood. Prenat Diagn 2004;24: 293-297.

-16 Smid M, Galbiati S, Lojacono A, et al: Correlation of fetal DNA levels in maternal plasma with Doppler status in pathological pregnancies. Prenat Diagn 2006;26:785-790.

17 Nicolaides KH: Turning the pyramid of prenatal care. Fetal Diagn Ther 2011;29:183-196.

18 Robinson HP, Fleming JE: A critical evaluation of sonar crown rump length measurements. Br J Obstet Gynaecol 1975;82:702710.

-19 Syngelaki A, Chelemen T, Dagklis T, Allan L, Nicolaides KH: Challenges in the diagnosis of fetal non-chromosomal abnormalities at 1113 weeks. Prenat Diagn 2011;31:90-102.

-20 Wright D, Kagan KO, Molina FS, Gazzoni A, Nicolaides KH: A mixture model of nuchal translucency thickness in screening for chromosomal defects. Ultrasound Obstet Gynecol 2008;31:376-383.

-21 Plasencia W, Maiz N, Bonino S, Kaihura C, Nicolaides KH: Uterine artery Doppler at 11 +0 to $13+6$ weeks in the prediction of preeclampsia. Ultrasound Obstet Gynecol 2007; 30:742-749.

-22 Kagan KO, Wright D, Spencer K, Molina FS, Nicolaides KH: First-trimester screening for trisomy 21 by free beta-human chorionic gonadotropin and pregnancy-associated plasma protein-A: impact of maternal and pregnancy characteristics. Ultrasound Obstet Gynecol 2008;31:493-502.
3 Brown MA, Lindheimer MD, de Swiet M, Van Assche A, Moutquin JM: The classification and diagnosis of the hypertensive disorders of pregnancy: statement from the International Society for the Study of Hypertension in Pregnancy (ISSHP). Hypertens Pregnancy 2001; 20:IX-XIV.

24 Poon LC, Volpe N, Muto B, Syngelaki A, Nicolaides KH: Birthweight with gestation and maternal characteristics in live births and stillbirths. Fetal Diagn Ther 2012;32:156-165.

25 Sparks A, Wang E, Struble C, et al: Selective analysis of cell-free DNA in maternal blood for evaluation of fetal trisomy. Prenat Diagn 2012;32:1-7.

26 Ashoor G, Poon L, Syngelaki A, Mosimann B, Nicolaides KH: Fetal fraction in maternal plasma cell-free DNA at 11-13 weeks' gestation: effect of maternal and fetal factors. Fetal Diagn Ther 2012;31:237-243.

27 Zdravkovic T, Genbacev O, McMaster MT, Fisher SJ: The adverse effects of maternal smoking on the human placenta: a review. Placenta 2005;26:S81-S86.

28 Jauniaux E, Burton GJ: The effect of smoking in pregnancy on early placental morphology. Obstet Gynecol 1992;79:645-648.

29 Carbillon L, Challier JC, Alouini S, Uzan M, Uzan S: Uteroplacental circulation development: Doppler assessment and clinical importance. Placenta 2001;22:795-799.

30 Anker P, Mulcahy H, Chen XQ, Stroun M: Detection of circulating tumour DNA in the blood (plasma/serum) of cancer patients. Cancer Metastasis Rev 1999;18:65-73.

31 Bret L, Lule J, Alary C, Appolinaire-Pilipenko S, Pourrat JP, Fournie GJ: Quantitation of blood plasma DNA as an index of in vivo cytotoxicity. Toxicology 1990;61:283-292.

32 Holdenrieder S, Stieber P, Forg T, Kuhl M, Schulz L, Busch M, et al: Apoptosis in serum of patients with solid tumours. Anticancer Res 1999; 19:2721-2724.

33 Giacona MB, Ruben GC, Iczkowski KA, Roos TB, Porter DM, Sorenson GD: Cell-free DNA in human blood plasma: length measurements in patients with pancreatic cancer and healthy controls. Pancreas 1998;17:89-97.

34 Haghiac M, Vora NL, Basu S, Johnson KL, Presley L, Bianchi DW, Mouzon SH: Increased death of adipose cells, a path to release cell-free DNA into systemic circulation of obese women. Obesity (Silver Spring) 2012; 20:2213-2219.
35 Levine RJ, Qian C, Leshane ES, et al: Two stage elevation of cell-free fetal DNA in maternal sera before onset of preeclampsia. Am J Obstet Gynecol 2004;190:707-713.

36 Crowley A, Martin C, Fitzpatrick P, et al: Free fetal DNA is not increased before 22 weeks in intrauterine growth restriction or pre-eclampsia. Prenat Diagn 2007;27:174-179.

37 Sifakis S, Zaravinos A, Maiz N, et al: First-trimester maternal plasma cell-free fetal DNA and preeclampsia. Am J Obstet Gynecol 2009; 201:472.e1-e7.

38 Illanes S, Parra M, Serra R, Pino K, FigueroaDiesel H, Romero C, Arraztoa JA, Michea L, Soothill PW: Increased free fetal DNA levels in early pregnancy plasma of women who subsequently develop preeclampsia and intrauterine growth restriction. Prenat Diagn 2009;29:1118-1122.

\$3 Alberry MS, Maddocks DG, Hadi MA, Metawi H, Hunt LP, Abdel-Fattah SA, Avent ND, Soothill PW: Quantification of cell free fetal DNA in maternal plasma in normal pregnancies and in pregnancies with placental dysfunction. Am J Obstet Gynecol 2009; 200:98.e1-e6.

-40 Sekizawa A, Jimbo M, Saito H, Iwasaki M, Matsuoka R, Okai T, Farina A: Cell-free fetal DNA in the plasma of pregnant women with severe fetal growth restriction. Am J Obstet Gynecol 2003;188:480-484.

41 Bianchi DW: Fetal DNA in maternal plasma: the plot thickens and the placental barrier thins. Am J Hum Genet 1998;62:763-764.

42 Farina A, LeShane ES, Romero R, et al: High levels of fetal cell-free DNA in maternal serum: a risk factor for spontaneous preterm delivery. Am J Obstet Gynecol 2005;193:421425

43 Leung TN, Zhang J, Lau TK, Hjelm NM, Lo YM: Maternal plasma fetal DNA as a marker for preterm labour. Lancet 1998;352:19041905.

44 Jakobsen TR, Clausen FB, Rode L, Dziegiel MH, Tabor A: High levels of fetal DNA are associated with increased risk of spontaneous preterm delivery. Prenat Diagn 2012;32:840845

45 Illanes S, Gomez R, Fornes R, et al: Free fetal DNA levels in patients at risk of preterm labour. Prenat Diagn 2011;31:1082-1085. 